\title{
The Specifics of Detective Activity in the Balkan Countries
}

\author{
Dragan Trivan, PhD \\ SERBIAN ASSOCIATION OF CORPORATIVE SECURITY MANAGERS \\ E-mail: dtrivan@gmail.com \\ Iztok Podbregar, PhD \\ University of Maribor, Faculty of Organizational Sciences \\ E-mail:iztok.podbregar@fov.uni-mb.si \\ Dragan Mijovic, PhD
}

\begin{abstract}
Detective activity is recent phenomena in post-authoritarian and post-conflict countries, which particularly applies to the region of the Balkans. Legislation of the Balkan countries faced similar challenges in the process of defining detective activity, and to an extent, in a similar way have addressed this phenomenon, with certain specifics related to the level of technological and cultural development. A significant impact came from the obligations in the process of accession of these countries to the European Union. In the Balkan countries, there is no unified opinion on whether detective activity should be regulated through specific laws or fit into a legislation applicable to private security sector as a whole. In these countries, detectives were given legal opportunity to perform the job independently or within the registered legal entity, with a tendency for similar authorizations. Prevailing opinion is that detective activity is fitted in the zone of responsibility of the ministries of interior, thus, in the zone of responsibility of the police department.

Generally, in the Balkans, government regulations and executive are ahead of "market regulation". There are therefore several licenses, state training programs and other forms of state intervention in detective activity. It is also characteristic that the legislation in these counties differently recognizes required adoption of the Code of
\end{abstract}




\section{Seccurity}

private detective ethics. Detective activity in practice in the Balkan faces numerous concerns regarding the collection and processing of personal data without consent, given that the private detective is a product of the Anglo-Saxon legislation, and on the other hand, there is a universal right to the privacy, which includes a range of rights (right to the protection of personal data, the right to moral and physical integrity, the right to a private and family life - respect for correspondence, etc.). It is certain that the implementation of European standards in this area in the Balkans will not be an easy task, neither will always the regulations produce the expected outcomes.

Key Words: detective activity, countries, the Balkans, legislation, practice.

\section{Introduction}

Detective work reduces the police involvement in the cases that are not a priority, particularly in the scope of private and corporate investigations, and on the other hand, it relieves service users which find easier to cooperate with private investigators than with bureaucratic and overly work-loaded police officers. Experience in the practice shows that detectives can often be more successful than the state police, among other things, because they don't hassle with bureaucratic trivialities and because they are willing to pay for useful information.

Although operating locally, private investigators are involved in wider range of security because their engagement often exceeds the state borders and for the purpose of efficiency and timely resolution of the case, a detective agency often takes over surveillance and data collection in their own country (Magerl Krivanek, 2014).

Legal and effective detective job performance requires an appropriate legal framework governing the basics, including but not limited to job requirements, licenses and work permits, organizational forms, detective authority, etc. In addition, there's no doubt that encouraging entrepreneurial initiatives in the field of private security is not realistic without national legislation and implementation of current international standards (van Amstel, 2015).

The necessity of legal regulation of detective activity comes from it, not always, clearly-defined relationship to operative work of the police department. Namely, it is necessary to draw a clear line between the scope of work of private investigators and 
the jobs that are in the exclusive jurisdiction of the state police, which in practice may overlap. Here it should be highlighted that there are operational actions and measures applied by the police and which, by the nature of the business, can be applied by detectives in providing services for the service users (Šelih and Završnik, 2012). In post-authoritarian and post-conflict societies, the role of detective activities should be seen in the context of the dramatic changes in recent decades, i.e. through the prism of the reform of the security sector in these countries, in which weakened government institutions have not been able to preserve the monopoly of the statepower, while the newly established private security entities were able to fill the resulting gaps by taking excess of personnel in the police, intelligence, and the military. Widespread corruption in these countries attracted individuals in the private sector, but also in the public sector to grab the opportunity to charge for provided security services. Security has become such a commodity like any other, regardless of who is offering it (Babikov, 2005).

\section{Standards and Practices of Contemporary Detective Activity}

The comparison of detective work worldwide shows a number of specific characteristics, starting with terminology, the position and role of private investigators in the security system, to the degree of legal regulations. The differences are particularly present among the Anglo-Saxon legal tradition and European continental states (Batelaan and Bos, 2006).

Legal regulation of detective activity in Europe is also diverse. Most European countries in the last 30 years have passed the laws governing private security, and within that, the private detective activity. Only part of the national legislation contains specific regulation related to detective activity. In some countries, such as Austria and Germany, the entire sector of private security is regulated with the provisions of other laws, mostly in the field of general economic and industrial regulations. Some of the European countries do not regulate this field centrally, but on the cantonal, regional, or local level, such as Switzerland, Italy, and Bosnia and Herzegovina (George and Button, 2000).

Normative regulation of detective activity also remains a new subject for the national legislation of Member States of the European Union. At the EU level, there is 


\section{Seccurity}

no even a unified standpoint if the field of private investigations in general needs exact legislation or all specifics can fit into the overall legal regime that applies to all other activities. It is though characteristic that the distinct laws on Detective activity was passed mostly by new Member States of the European Union (Button, 2007). It is obviously that this have taken place due to reforms in security sector, i.e. meeting the requirements for obtaining membership in international organizations such as the European Union or NATO (Yusufi, 2004).

One of the most important initiatives in the field of private investigation is considered a "Minimum common standards of the European Union concerning the licensing of investigation in the private sector"; a document presented 2008 at the International Federation of Associations of Private Detectives (IKD). The Association, which operates since 1964 with the objective of establishing the highest standards in this area brings together the detective associations from 22 European and non-EU countries, has offered to the European Union institutions a proposal with analysis of the situation in the EU and suggestions of minimum common standards in the performance of private investigation. By IKD definition, private investigation includes surveillance, interrogation and investigation directed towards a specific person, for the purpose of obtaining information or data from records, relating to particular persons or their activities, as well as the circumstances and ways in which a particular asset or thing may have been damaged or lost. Accordingly, private investigators can provide clients with the following services: investigation of accidents; blackmail investigation; investigations related to accounting, forgery, intellectual property, family and marital relationships, missing persons and things; legal interpretation; litigation assistance; the gathering of evidence; returning a property; situation analysis; supervision; theft investigation and trace expertise (Travers, 2011).

\subsection{Detective Activity and Protection of Human Rights}

Current detective industry is faced with the question of the legal basis under which private investigators collect and process personal data without persons' consent, taking into account that the private detective is a product of the Anglo-Saxon legal system, where there are private criminal investigations, and in the performance of private investigation, investigators may collect, process and use personal data without the consent and approval of that person (Hakala, 2008). 


\section{Secururity}

Contrary, there is a universal right to the privacy, including the right to respect of private and family life, home and correspondence, honor and reputation (Prenzler and King, 2002). In a democratic country, any restriction of human rights must be provisioned by the law, which means that deviation from standards in this area must be legitimate, so that it would not be in significant extent undermined. Restriction of these rights has to be explained with some of the recognized goals, which include the protection of the rights and freedoms of others, public order, moral, prevention of conflicts and crime. This limitation is necessary and proportional, and not arbitrary, unfair, discriminatory or based on irrational perspectives (Trivan, 2014).

For example, in the Republic of Serbia the protection of personal data is stipulated in the Article 42 of The Constitution, which demands that the collection, possession, processing and use of personal data is regulated by the law. Accordingly, it is forbidden and punishable use of the data beyond the purpose for which the data was collected, except for the purpose of conducting criminal proceedings or national security in a manner stipulated by the law. In addition, the right to privacy is constitutionally protected and guaranteed through a protection of human dignity, inviolability of physical and mental integrity, home, and correspondences. An exception to the constitutional protection is stated in the Article 13 of the Law on protection of personal data, by which a government staff can process personal data without consent, if the processing is necessary in order to carry out jobs within its competence determined by the law or other regulation, for the purpose of national security, public order; the country's defense; prevention, exposure, investigation and prosecution of crimes, economic thus, financial interests of the country, protection of public moral and health, protection of rights and freedoms and other public interests, and in other cases with written consent of the person whose data has been collected. In this regards, solutions contained in the Law on Detective Activity of the Republic of Serbia are characterized by restrictive relationship in terms of possibilities for personal data collection and processing, while the legal provisions themselves are quite obscure and incomplete. Namely, the Law on Detective Activity have tied detectives in performing their jobs by the legislation in domain of personal data protection and the free access to information of public importance. Therefore, it is provisioned that the detective who collects the personal data, on that person's request, must show the detective badge and the power of attorney, and thus, the processing of data without consent is permitted in accordance with regulations governing the protection of personal data. It is also 
stipulated that the detective will be denied information classified as secret (Petrovic, 2014).

On the other hand, part of the criticism of the provisions of the Law on detective activity about personal data processing in Serbia highlights their flexibility, with indications that the private investigators have gained a realistic opportunity for serious breaks in persons' privacy. Also, per statutory formulation "the justified request" has to be considered on particular merits of the request. Consequently, a question arises concerning criteria by which the "handlers of the records" (approximately $350,000)$ will grade those merits, risking discrimination among petitioners of "the justified requests" and enabling effortless data access to some of petitioners on corruptive, political, family, friendly, or any other basis (Trivan, 2015).

\section{The General Status of Detective Activity Legislation in the Balkans}

In the recent decades, all the Balkan countries have enabled legal conduction of private investigation, with certain differences in normative regulations. Detective activity is nationally regulated with specific laws in the Republic of Croatia, Greece, Romania, Montenegro, Serbia, and the Republic of Macedonia. In Bosnia and Herzegovina field of private investigation is not centrally regulated, while the laws have been passed in the Republic of Srpska and Brcko District. In the entity of the Federation of Bosnia and Herzegovina there are some procedural problems (the Bill is blocked in one of the two parliamentary houses). In the Republic of Bulgaria, the Republic of Albania and the self-proclaimed Republic of Kosovo there are only laws that regulate the private security which individual provisions indirectly regulate questions concerning private investigations. On the basis of passed laws in these countries, the activity of private investigators is specifically regulated with bylaws (Bakreski and Associates, 2015).

Almost all the states' laws of the Balkans stipulate a similar scope of competences and powers. If you review the list of jobs of private investigators issued by UK Professional Investigators Network (UKPIN), restrictions in operation of private investigators in the Balkans are notable. In fact, by UKPIN private detective scope of work includes battling corruption, assistance in children adoption and custody, assistance in executions (confiscation of property) and bankruptcies, the search for the 


\section{Seccurity}

invaders and persons that impose threats and blackmail, companies support in collection of payments, check in criminal cases, assistance in criminal procedures (complaint, appeal, defense), computer crimes, collection of traces for DNA analysis, GPS/GSM commodity tracking etc. (Draz and Associates, 2009).

Comparative analysis of legislation shows that the detective activity is generally defined as the collection of data, their processing and delivery to the service user. Private investigators in the Balkans have been given the legal opportunity to perform their job independently or in joint private investigation office (the Agency, Office, Company). Control and inspection of detective activity is mostly conducted by the ministries of interior and/or by the authorized sections of the police department. Noticeable is also the trend of similar statutory powers in conducting job for a client/service user. Detectives, in general, are permitted to collect data and information from persons who are willing to provide such information, thus, directly from individuals whose information is collected, and from other persons who have awareness of such information (only on a voluntary basis), as well as through means of public information (Trivan, 2014).

\subsection{Standards and Practices of Detective Work in the Balkan Countries}

Detective activity in the Republic of Croatia is regulated in 2009 with the Law on private detectives. By then, work of private investigators was regulated with specific provisions of the Law on protection of persons and property. The law defines detective activity as collection of data necessary for determination of the facts, use and processing personal data and other information for service user. Hence, a detective can collect information about: missing persons or persons who are hiding from the service user, persons who have written or sent anonymous letters or persons who are slandering, insulting or disclosing something about personal, family, or professional life that can hurt someone's honor or reputation; persons who have caused a harm to a service user; items that are lost or stolen; evidence needed to a service user for fulfilment of the rights or privileges granted by judicial or other government bodies and committees or associations; effectiveness of the work performance; success and/or professionalism of the companies, entrepreneurs, and other legal entities; the facts and circumstances pertaining to the personal state of individuals and status of their property; employment applicants and employees only with their written consent and in 


\section{Seccurity}

accordance to a special regulation governing employer authorization to collect such information; crimes and their perpetrators (private criminal proceedings), and violations of work duties or work discipline. Within stated above, a private investigator is allowed to perform surveillance, monitoring and photographing in public places (Joksić, 2013).

The law also stipulates preventive role of private investigators, related to the protection of business confidential information, IT systems thus, protection of business and personal data and information. Authorization and work permits are issued by Ministry of Interior that also performs supervision and inspection of private detective activity. The law leaves the space that in Croatia, private investigation can be performed by professionals whom bodies of other Member States of the European Union or states that have signed the Agreement on the European economic area have issued private detective work authorization (Nađ, 2012).

There are 120 licensed detectives, 11 licensed agencies, and 9 entrepreneurs operating in Croatia. 8 of them are members of Private Investigation Group in the Croatian Chamber of Commerce. Private investigation in Croatia is characterized by uneven regional distribution so that, for example, in the region of Slavonia there isn't a single registered detective agency (Radić Ančić and Antolić, 2016).

Private investigation in Romania is regulated by the Law on private detectives No. 328 from 2003. Private detective agencies and detective offices require necessary licenses for work, issued by the General Inspectorate of Romanian police (IGPR). Licenses are issued by the Ministry of Interior and Administration. Detectives in Romania are not allowed to conduct operations in sole jurisdiction of the state police, or apply secret surveillance of communication. Founding and operation is equally granted to domestic and foreign entities (from Member States of the European Union). Private investigation can be performed from detective agency, or an office. Private security companies are not allowed to conduct detective work. Detectives are not allowed, at the same time, to practice law-legal services, and they have to report to the police any awareness about committed crime. Also, private investigators must respect human rights in performing their job. (Prisacariu, 2010).

Romanian detectives are legally authorized to collect data and information, perform investigation and surveillance concerning verification of conduct and moral character of persons, marital and family issues, solvency and reliability of the legal entities and business partners, fidelity of submitted Curriculum Vitae, insurance fraud, counterfeiting of trademarks and brands, missing persons, missing and stolen items, 
family origin, and protection of data and information from unauthorized access and business espionage.

In 2012 in Romania there were about 500 domestic and foreign legal entities and entrepreneurs with more than 2000 employed licensed detectives. About $50 \%$ of the resources have been located in the wider area of Bucharest. Detectives in Romania are voluntarily united in the Romanian Association of Private Detectives - AODPR (Mironov Banuta, 2012).

In the Republic of Bulgaria there isn't a specific law on detective activity neither are private investigators explicitly mentioned in the Law on private security from 2004, amended 2011 and in 2014, nor in any other legal act (Bulgaria Investment and Business Guide, 2016).

Regardless of the absence of an adequate regulatory framework, in Bulgaria operate branches of EU detective agencies, and a significant number of private security companies for personal and corporate protection actually perform investigation for their clients. In addition, a wide range of detective services in Bulgaria take place in the widespread grey zone, where employees did not receive adequate professional training (Dzekova and Kojouharov, 2016). A number of legal entities and entrepreneurs engaged in private investigations are incorporated in national voluntary association - the Bulgarian Association of private investigators (Българска асоциация на частните детективи - БАЧД), that passed the Statute and Code of ethics and operates through 8 regional subsidiaries.

Before the adoption of a special law No. 3206 in late 2003, the activities of private investigators in the Republic of Greece were covered by certain provisions of the Law on private security from 1997. Term detective is not common in Greece, instead, they use a private investigator term to distinguish professionals in this field from others, which in comparison to the other Balkan countries has a wider scope of activities, with emphasis on private and corporate investigations, secret surveillance and monitoring (Travers, 2011).

Private investigation in Greece, among other things, covers: finding missing persons and persons who are hiding from service user, marital infidelity, domestic theft, children deviant behavior, prevention of drug abuse, detection of sects, employment screening, tax fraud, DNA analysis, location of mobile phones. Private investigators must obtain work authorization issued by regional police directorates. 


\section{Seccurity}

It is estimated that there are about 120 agencies and independent investigators in Greece, more than 80 of them operate in the area of Athens (Papanicolaou, 2006). Majority of private investigators are former police officers. They must be Greek citizens, or nationals of some of the Member States of the EU and with clean criminal record. Five years before applying for a work permit, they must not be employed by the police or other security service, customs, telecommunications company and/or the stock exchange.

In the Republic of Macedonia legislation in domain of private investigations refers to the Law on detective activity from 1999, amended in 2007 and 2008. The law defines a private investigation as collection of data and information, its use and processing in a lawful manner (Bogunović, 2013). Law, stipulates a license for private detectives issued by Ministry of Interior. Detectives are not allowed to conclude agreements on matters that are exclusively within the jurisdiction of the government authorities, to work for domestic or foreign government bodies or political parties, nor to deal with affairs related to debt collection. Also, detectives are forbidden to use weapons and other means of coercion, as well as to use the means and methods that are prohibited by law or in explicit jurisdiction of government authorities (Bakreski and Associates, 2015).

Detective activity is, in sort of a way, a new profession in Macedonia and we cannot get enough of the relevant data by now about detective agencies performance in practice. Problems faced by private investigators in Macedonia refer to financial interest in performing these activities, beside other, because of the expensive equipment that increases the price of services in a relatively poor society. One of the problems arises from the partially achieved reform of the security sector thus, unresolved questions of communication and information exchange between public and private sectors. Also, the difficulties are related to the facts that the evidence investigators collect, for example in marital infidelity or business espionage, are not valid in court proceedings. Problems also arise when it comes to obtaining the necessary professional competence for conducting private investigation (Slaveski and Bozinovska, 2016).

Supervision over implementation of the Law on detective activity is performed by the Ministry of Interior. In this regard, detective is obliged to enable authorized representatives of the Ministry of Interior to conduct inspection, to provide with requested documents and to give necessary information and data, except about the content of concluded contracts. In the case of non-compliance with the legal provisions, 


\section{Seccurity}

the Ministry of Interior can order detective to correct the observed deficiencies within a maximum of three months (Trivan, 2014). Hence, in the Republic of Macedonia, currently operate 7 detective agencies.

In Montenegro, the activities of private investigators are regulated by the provisions of the Law on detective activity from 2005, amended in 2008 and 2011. This legal act governs founding and conducting private investigation, rights and responsibilities of detectives, as well as questions about control and supervision. Detectives in Montenegro are not allowed to apply the means of coercion, nor to apply means and methods that are in the exclusive jurisdiction of government authorities. On the basis of collected data, detective can submit a case to applicable government body on behalf of his client. The same can be done without the consent of the client in case of committed offences prosecutable ex officio (Rizmal and Vojinovic, 2014).

Supervision and control over implementation of the Law on detective activity is performed by the Ministry of Interior; the Department for supervision of entities dealing with protection of persons and property, and private investigations (Trivan, 2014). There are 2 detective agencies and 8 detectives in Montenegro engaged in business of private investigation.

Bosnia and Herzegovina doesn't have an umbrella law about detective activity, which opens the opportunity for discrepancies and illegal activities in this field (Lakača, 2014). In Federation of Bosnia and Herzegovina there is a Law on agencies and internal sections for protection of people and property from 2008. This law does not cover detective activity at all. A draft law on private detectives of the Federation BiH was adopted by House of Representatives of the Parliamentary Assembly in February 2010, but was never discussed in House of peoples (Ahić, 2015).

The Law on agencies for security of persons and property and private detective activity of the Republic of Srpska from 2002 for the first time in BiH addresses detective activity, detective job performance, rights and responsibilities of private detective agencies and detectives, and supervision of their work. The National Assembly of the Republic of Srpska in 2012 has adopted a new Law on agencies for security of persons and property and private detective activity, by which detective activity involves tasks such are; data and evidence collection and processing performed by professionals authorized to do detective work (Bakreski and Associates, 2015).

Detective activity in BiH, District of Brcko, is regulated by the Law on agencies for security of persons and property and private detective activity from 2004, which 
provisions are almost identical to related legislation in the Republic of Srpska. Agencies authorized to conduct private investigation are prohibited to provide service for authorities of District of Brcko and its representatives, as well as for domestic or foreign defense, security, or counterintelligence agencies (Trivan, 2014).

In Bosnia and Herzegovina, the demand for the private detective services is not as noticeable as in other countries in the Balkan region. In the Republic of Srpska there are 2 detective agencies -1 in Banja Luka and 1 in Milići. In the absence of legislation in the Federation of $\mathrm{BiH}$, in Sarajevo, there is only one business registered as agency for business security.

Detective activity in the Republic of Albania is not legally regulated, and the business of private investigation is indirectly incorporated in the provisions of the Law on private security services from 2014, related to the area of personal and corporate security. In Albania, there are not licensed domestic detective agencies and private detectives, while private investigation services, not too demanded, are often taking place in the grey zone. Some private security companies in Albania offer private investigative services. Also in this area operate the branches of certain foreign companies that provide private investigative service, such as Greves Group or Eagle Eye Group (Dyrmishi, Çami, 2016). Very similar situation is in self-declared Republic of Kosovo, where in 2011, the Law on private security services was passed, which provisions do not include detective activity. This, however, does not mean that in Kosovo do don operate private investigators, but their activities are taking place or in gray zone of business, or within registered company for private security and protection (Blease and Qehaja, 2013).

\subsection{Detective Activity in the Republic of Serbia}

In November 2013, the Republic of Serbia passed the Law of detective activity that was the first legislation to deal with private investigations. The law regulates business entities, entrepreneurs and individuals that, in the Republic of Serbia perform detective work, licensing requirements, the nature of business operations and supervision over their work. Law stipulates that detectives cannot apply operational and technical means and methods which are exclusively within the jurisdiction of the government authorities. All competencies in regards to control and supervision over 
implementation of the Law on detective activity are entrusted to the Ministry of Interior.

Detective activity in Serbia includes collection and processing of data and information about: missing persons or persons who are hiding for the purpose of avoiding criminal prosecution; persons who have caused damage to clients if legal requirements for damage liability have been fulfilled; persons who anonymously and unlawfully act towards clients with a threat of harmful consequences; lost or stolen property; effectiveness of legal entities and entrepreneurs; protection of intellectual and industrial property. Detective is legally obligated to report a crime prosecuted ex officio in a case when he/she obtains an information about such crime while performing detective job (Trivan, 2014).

Some professionals believe that detective data processing is not in accordance with the Law on personal data protection, and that certain provisions of the Law on detective activity authorize detectives to search for missing persons or personas who are hiding, placing them in the position of so-called para-police force. Accordingly, it is noted out that, for example, persons with criminal background could hire a detective to disclose protected witnesses (Petrovic and Milosevic, 2015).

The Ministry of Interior of the Republic of Serbia have passed 4 delayed bylaws to support implementation of the Law on detective activity. Therefore, there was a significant breach of terms for its application and implementation, thus, synchronizing the activities of business entities and entrepreneurs with legal provisions was overdue. This is especially notable in legal provisions regarding professional training and examination in the Ministry of Interior in the process of professional licensing. Else, the requirement for obtaining a license to conduct private investigation are the Act of job systematization and at least two employed detectives for legal/business entity, or at least one employed licensed detective for entrepreneur.

The law stipulates that the license for detective activities shall be issued to an individual that is a citizen of the Republic of Serbia, has at least higher education at studies of the first degree (undergraduate studies and basic vocational studies) and/or studies lasting up to 3 years, has passed corresponding security check, has psychophysical abilities for detective work, has completed training program and passed the exam for a detective before the Commission of the Ministry of Interior (Bakreski and Associates, 2015). 
During 2016 Ministry of Interior carried out two training cycles and professional exams for employees in private detective agencies. In this regard, by March 2017, 4 detective agencies and 28 individuals have obtained licenses for conduction private investigations. A disharmony of legislation and practices is notable, considering that the Group for detective activity, at the Serbian Chamber of Commerce, has 16 legal entities members, previously registered for this activity. In addition, it is estimated that in Serbia there are another twenty non-licensed legal entities that perform detective business. Else, according to unofficial estimates, between 3000 to 4000 thousand people utilize private detective services in Serbia.

It is still unknown how many private security companies, business, insurance companies and banks, temporarily or permanently engage persons for providing private investigation services (Petrovic and Milosevic, 2015).

\section{Conclusion}

In all the Balkan countries, there is, to the greater or lesser extent, a detective activity, whose operators seek to gain their place in the market for private security services. It is characteristic that in most of these countries, because of decades of communism, for almost 50 years there was a disconnect when it comes to the performance of private investigations.

Comparative practice in the Balkan countries shows that the scope of detective activities is quite similar, meaning that detective activity typically involves the search for missing persons and things, investigation of crime, surveillance and monitoring, preventive activities focused on detection of listening devices and undercover surveillance, polygraph, alarms and video surveillance implementation, corporate investigations, investigation of business partners solvency, security consulting, marital infidelity, employment screenings, preparation of participants in court proceedings for testimony, youth delinquency and drug abuse, ant-diversion protection, protection of property and persons employed abroad, identification of mitigating and aggravating circumstances in criminal proceedings, personal data and private information collection, and education and training of candidates for private detectives. 
Supervision and control over the work of private detectives in the Balkan countries are primarily implemented by the relevant police sectors of the ministries of interior, while other forms of inspection are not noticeable in practice.

Legislation in domain of private investigation in the Balkan countries is generally consistent with prevailing international trends in this field. Otherwise, even at the EU level unified standards about private investigation are not common. Also, there are no rounded regulations in all the Member States of EU; visible are different procedures and criteria, there is unequal crime tolerance, and there is no comprehensive model to serve as an example.

On the other hand, EU Member States have started the process of downsizing in the police department, thereby decreasing the budget, while the number of authorizations and activities that can be performed by the private sector increases, providing the opportunity for new staff and for retired police officers who meet the criteria stated in the laws on detective activity. This also affects the social usefulness of the individual, while society gets experienced experts who can continue their activities in battling the crime.

There's no doubt that the legislation of all the Balkan countries had similar issues, dilemmas and problems, and that the filed was addressed similarly, in some cases identically. This especially applies to the conditions for conducting private investigations, the rights and responsibilities of private investigators, that are in all the national laws of these countries almost exactly regulated, with some terminological differences coming from the level of achieved technological and cultural development.

Private investigation practice in the Balkan countries frequently reveals information and evidence not relevant to the job for which they are engaged, but these require further investigation, for which reason the laws on detective activity of each of these countries stipulates an obligation of private investigators to report the crime.

There has been a certain shift in these countries in regards to cooperation among private detectives and police officers in domain of evidence collection, especially in domain of surveillance and monitoring, thereby decreasing the work-load of the police in the field, that can, therefore, allocate its resources towards resolving more prioritative crimes. 


\section{References}

1. Ahić J. (2015). „Harmonizacija zakonske regulative privatne sigurnosti u Bosni i Hercegovini u kontekstu evropskih integracija". U: Zbornik radova Međunarodne naučno-stručne konferencije "Usklađivanje zakonodavstva sa Acquis-em". Sarajevo: Internacionalni Burč univerzitet, str. 163-178.

2. Babikov V.G. (2005). 40П: От созданиа до успеха, Москва: НОУ ШО „Баярд” \& Школа охраньі Баярд.

3. Bakreski 0. et. Al. Privatna Bezbednost - teorija i concept. Skopje: Komora na Republika Makedonija za privatno obezbeduvanje.

4. Batelaan H. Bos J.(2006). International Security Guards and Investigators: Survey of Regulations on Private Security and Investigation in Si EU Countries. Amsterdam NL: Regioplan.

5. Blease D. Qehaja F. (2013). "The conundrum of local ownership in developing a security sector: The case of Kosovo". In: New Balkan Politics, Vol. XIV, No. 14, p.p. 3-23.

6. Bogunović N. (2013). „Industrija privatne sigurnosti u Republici Makedoniji - Od jednoetničkih podjela do evropskih standarda". U: a\&s Adria magazin, Vol. VIII, br. 83, str. 54-55.

7. Bulgaria Investment and Business Guide (Vol. 1) - Strategic and Practical Informations. (2016). Washington DC: International Business Publications.

8. Button M. (2007). „Assessing the Regulation of Private Security across Europe“. In: European Journal of Criminology, Vol. IV, No. 1, p.p. 109-128.

9. Draz W.D. et. al. (2009). Introduction to Proffesional Investigations - Concepts \& Strategies for Investigators in the Private Sector. San Clemente CA: LawTech Publishing Group.

10. Dyrmishi A. Çami 0. (2016). "The Evolving Functions of Private Security in a Small Community in Albania - The Case of Vaqarr", In: Klopfer F. van Amstel N. (eds). Private Security in Practice - Case studies from Southeast Europe. Geneva: DCAF, p.p. 15-23.

11. Dzhekova R. Rusev A. (2015). "Bulgaria“. In: Klopfer F. van Amstel N. (eds), $A$ Force for Good? Mapping the private security landscape in Southeast Europe. Geneva: DCAF, p.p. 31-59.

12. George B. Button M. (2000). Private Security. London: Palgrave Macmillan. 


\section{Seccuritity}

13. Hakala J. (2008). Why regulate manned private security?. Wemmel BL: Confederation of European Security Services (CoESS).

14. Joksić I. (2013). "Zakonska regulisanost detektivske delatnosti u Hrvatskoj". U: Strani pravni život, Vol. LVII, br. 1, str. 255-271.

15. Lakača S. (2014). „Poslovi privatnih detektiva u urbanim sredinama“, U: Naučna konferencija "Sigurnost urbanih sredina" - zbornik radova. Sarajevo: Fakultet za kriminalistiku, kriminologiju i sigurnosne studije, str. 27-35.

16. Magerl Krivanek A. (2014). „Privatni detektivi i Adriatic regija”. U: a\&s Adria magazin, Vol. IX, br. 96, str. 48-49.

17. Mironov Banuta D. (2012). „Detectiv de România sau cum să filezi profilul”. In: Income Magazine, Vol. II, No. 21, p.p. 25-26.

18. Nađ, I. (2012). Zbirka propisa iz djelokruga privatne zaštite. Zagreb: Hrvatska udruga menadžera sigurnosti.

19. Papanicolaou G. (2006). "Greece“. In: Jones T.; Newburn T. (eds), Plural Policing - A Comparative LOPerspective, London: Routledge, p.p. 77-97.

20. Petrovic V. (ur.) (2014). Ljudska prava u Srbiji 2013 - parvo, praksa i medjunarodni standardi ljudskih prava. Beograd: Beogradski centar za ljudska prava.

21. Petrovic P. Milosevic M. (ur.) (2015). Novi-stari izazovi privatnog sektora bezbednosti u Srbiji. Beograd: Beogradski centar za bezbednosnu politiku.

22. Prenzler T. King M. (2002). "The Role of Private Investigators and Commercial Agents in Law Enforcement". In: Trends \& issues in crime and criminal justice, Vol. XVII, No. 234, pp. 1-6.

23. Prisacariu, C. (2010). „Romania: New system, same players“. Organized Crime and Corruption Project - $\quad$ OCCRP. http://www.reportingproject.net/security/index.php/stories/7-romania. (pristupljeno 02.03.2017).

24. Radić Ančić N. Antolić J. (2016). „U Hrvatskoj ih je 120: Detektivi otkrivaju kako uhode i prisluškuju bračne partnere!“. Riječanin. 2.3.2016. http://www.rijecanin.rtl.hr/u-hrvatskoj-ih-je-120-detktivi-otkrivaju-kako-uhodei-prisluskuju-bracne-partnere/ (pristupljeno 09.03.2017).

25. Rizmal I. Vojinovic T. (2014). “Privatno obezbedjenje bez javno-privatnog partnerstva I sa njima"/ U: Svet bezbednosti, broj 3, str. 64-66. 
26. Slaveski S. Bozinovska F. (2016) „Приватната детективска дејност во Репубика Македонија: искуства и перспективи“. У: Зборник "Приватна безбедност во XXI век - искуства и предзивци". Скопје: Комора на Република Македонија за приватно обезбедување, str. 255-268.

27. Šelih A. Završnik A. (eds) (2012). Crime and Transition in Central and Eastern Europe. New York NY: Springer Science \& Business Media.

28. Travers J. (2011). The Original Private Investigator's Handbook and Almanac. Raleigh NC: Lulu.com.

29. Trivan D. (2014). "Detektivska delatnost". Beograd: Dosije studio.

30. Trivan D. (2015). "Detektivska delatnost i zastita podataka o licnosti". U: Svet bezbednosti, Vol. X, broj 1, str. 46-48.

31. van Amstel N. (2015). "Understanding the Shared Context of Private Security regulation, In: Klopfer F. van Amstel N. (eds). A Force for Good? Mapping the private security landscape in Southeast Europe, Geneva: DCAF, p.p. 107-117.

32. Yusufi I. (2004). "Understanding the Process of Security Reform in Southeastern Europe", In: Journal of Security Sector Management, Vol. II, No. 2, pp. 1-18. 